\title{
Zinc Induced Histopathological Alternations in Gill, Liver, and Kidney of Freshwater Fish Gonoproktopterus kolus (Sykes)
}

\author{
Karanjkar D. M.*, V. Y. Deshpande \\ P. G. Department of Zoology, Yashavantrao Chavan Institute of Science, Satara (Maharashtra), India
}

Received April 1, 2020; Revised June 11, 2020; Accepted June 16, 2020

\section{Cite This Paper in the following Citation Styles}

(a): [1] Karanjkar D. M., V. Y. Deshpande, "Zinc Induced Histopathological Alternations in Gill, Liver, and Kidney of Freshwater Fish Gonoproktopterus kolus (Sykes)," Advances in Zoology and Botany, Vol. 8, No. 5, pp. 400 - 407, 2020. DOI: 10.13189/azb.2020.080504.

(b): Karanjkar D. M., V. Y. Deshpande (2020). Zinc Induced Histopathological Alternations in Gill, Liver, and Kidney of Freshwater Fish Gonoproktopterus kolus (Sykes). Advances in Zoology and Botany, 8(5), 400 - 407. DOI: 10.13189/azb.2020.080504.

Copyright $\odot 2020$ by authors, all rights reserved. Authors agree that this article remains permanently open access under the terms of the Creative Commons Attribution License 4.0 International License

\begin{abstract}
The present study aims to investigate the histopathological changes in gill, liver, and kidney of fresh water fish Gonoproktopterus kolus (Sykes). The fingerlings of fish were exposed to Zinc (Zinc sulphate) in acute toxicity experiment $\left(96 \mathrm{hrs}\right.$.). The $\mathrm{LC}_{0}$ and $\mathrm{LC}_{50}$ concentrations were $2.430 \mathrm{ppm}$ and $4.860 \mathrm{ppm}$ respectively. After acute exposure, fish were sacrificed and tissues were obtained separately from control and $\mathrm{LC}_{0}$ and $\mathrm{LC}_{50}$ groups. These tissues were fixed in Bouin's fluid and standard protocol was followed to study histopathological alterations in gill, liver and kidney of experimental fish. In gills, fusion and degenerative changes were observed in secondary gill lamellae. In liver, hepatocytes showed hypertrophy due to degenerative changes in cellular structure. Empty hepatocytes showed shifting of nucleus. Kidney showed degenerative nuclei in the epithelial lining of the tubule. Haemopoetic tissue showed hypertrophy and disarray. Distended glomerulus was observed. Renal tubules showed disarrangement as compared to control. Thus, in present investigation, it was observed that heavy metal zinc is affecting the fishes at tissue level, which may interfere in physiological processes.
\end{abstract}

Keywords Gonoproktopterus kolus, Gill, Liver, Kidney, Acute Toxicity, Zinc Sulphate, Histopathological Changes

\section{Introduction}

Heavy metal pollution is a serious problem in the aquatic ecosystem due to their ability to interfere in the food chain and accumulate in the aquatic organisms Berman [3]. Amongst the aquatic fauna, fishes are the important creatures in the study of heavy metal pollution, because they move freely within diverse trophic levels in an aquatic environment Chopra [6], Palaniappan, [25]. Study of histology is sensitive parameter and is very critical in detecting cellular alterations that may occur in target organs, such as the gill, liver and kidney.

Even though zinc, is an essential trace metal, it is toxic when the dietary supply becomes excessive Ho [12]. The main uses of zinc are in the manufacture of galvanized iron, bronze, paint (white), rubber, glazes, enamel glass, paper, as a wood preservative ( $\mathrm{ZnCl}_{2}$, fungicidal action), petrochemicals, and fertilizers, and steam generation power plants, etc. Nriagu [23]. Some zinc is released into the environment by natural processes, but most comes from the activities of people like mining, steel production, coal burning, and burning of waste. It attaches to a soil, sediments, and dust particles in the air. Zinc compounds can pass into the groundwater, lakes, streams, and rivers. Generally, zinc bound to soil particles. Zinc concentration moderately increases in water due to corrosion of drainage pipes, which are made of zinc. Thus, it enters in fish and other organisms Joshi [15]. Zinc (Zn) is one of the most 
significant traces elements in the body, which influences the biological function of some proteins and enzymes Maity [22].

Fish gill on the other hand is critical organs for respiration, osmoregulation, and excretion. Gills serve as a good indicator of water quality. They are sensitive to any change of water components since gill filaments and lamellae provide a very large surface area for direct and continuous contact with contaminants in water $\mathrm{Au}$ [2]. The fish liver is a vital organ concerned with basic metabolism, accumulation, biotransformation, and excretion of contaminants in fish Figueiredo [9]. One of the most important functions of the liver is to clean pollutants from the blood so it is considered as an indicator of aquatic environmental pollution Soufy [30]. The kidney is an important organ for the maintenance of homeostasis concerning water and salts, metabolic waste excretion from blood, and partially for the metabolism of xenobiotics Thophon [32]; Mabrouk [21]. Liver and kidney are considered as the crucial organs suitable for histopathological examination to study the damage to cells and tissues Rabitto [28]; Oliveira [24].

\section{Materials and Methods}

Live fingerlings of 7-8 $\mathrm{cm}$ in length and $10-12 \mathrm{gm}$ in weight were collected from the unpolluted Krishna River near Satara. Fishes were taken to the laboratory. Rectangular glass aquaria of dimension $45 \mathrm{~cm} \times 22 \mathrm{~cm} \times 30$ $\mathrm{cm}$ and capacity of 25 liters were used for stocking. Ordinary chlorine free tap water was used during acclimatization. Fishes were acclimatized for 15 days in the laboratory condition. Water was changed twice a day and fishes were fed with groundnut cake once in a day during acclimatization. $\mathrm{PH}$, dissolved oxygen and hardness of the water used for acclimatization was recorded. Before exposure of the fish to the metals, feeding was stopped for $24 \mathrm{hrs}$. The well-acclimatized fishes to the laboratory condition were used for experimentation. Group of 10 fingerlings was held separately in a plastic container of 20-liter capacity containing metals of different concentrations making a total volume of 10 liters. Experiment for zinc sulfate $\left(\mathrm{ZnSO}_{4}\right)$ was carried out and the test concentrations used were $1.620,2.430,3.240$, $4.050,4.860,5.670$, and $6.480 \mathrm{ppm}$. (Pilot experiments were carried out to find out the toxic range of zinc sulphate in milliliters. Then the established concentrations were converted into ppm.). The experiments were carried for 96 $\mathrm{hr}$ for the toxicity of the metals. The control group without toxicant was run simultaneously for every experiment. All the experiments were carried out on the natural day- light rhythm. Test concentrations from the experimental containers were renewed every 24 hours. The death rate and behavior of fishes were noted before each change of the water from the plastic container. The toxicity tests were repeated thrice, and for $96 \mathrm{hr} \mathrm{LC}_{0}$ and $\mathrm{LC}_{50}$ values 2.430 ppm and $4.860 \mathrm{ppm}$. Respectively, were recorded. After studying $96 \mathrm{hrs}$. acute toxicity of Zinc sulfate, selected body parts like gill, liver, and kidney belonging to $\mathrm{LC}_{0}$, $\mathrm{LC}_{50}$, concentrations along with control were removed and fixed in aqueous Bouin's fluid for $48 \mathrm{hrs}$. The tissues were then washed under tap water, dehydrated in ethyl alcohol grades, cleared in xylol, and embedded in wax. They were sectioned at 5-6 micron. Sectioned tissues were stained with Harris hematoxylin and alcoholic eosin and mounted in DPX. All the observations for microphotography were made under microscope Dewinter DEW/106.

\section{Results and Discussion}

\section{Histopathology of Gills:}

The normal histological structure and changes induced by the effects of heavy metal at acute concentration are shown in Figure No. I (Figure A to C).

\section{Control of Acute Test-}

The histological structure of gills of control fishes was normal having complete skeletal and lamellar parts. The ceratobranchial and epibranchial of each gill arch showed two rows of primary gill lamellae. It was seen that they were supported by bony elements. Primary gill lamellae gave rise to secondary gill lamellae from dorsal and ventral sides. Primary gill lamellae were lined by mucoidal epithelium. The secondary gill lamellae consist of a vascular network of capillaries reinforced by pillar cells (Fig.-1 A).

\section{Zinc Sulphate: Concentration 2.430 ppm:-}

Swelling of primary gill lamellae. Degenerative changes were seen in secondary gill lamellae, in some places they were completely damaged. There were breaks and cuts in the skeletal elements. Blood clots were found in some parts of the lamellae. The epithelium was also found detached from the skeletal elements (Fig -1 B).

\section{Zinc Sulphate: Concentration 4.860 ppm:-}

Due to exposure to this concentration, the changes were more drastic. Hyperplasia and hypertrophy were observed in the mucoidal epithelium. At many places, the fusion of secondary lamellae was seen. There was a reduction and loss of secondary gill lamellae. Blood clots were also seen in some places. Skeletal elements showed cuts, cracks and vacuolation. The epithelium was also found detached from the lamellae at many places (Fig -1 C). 


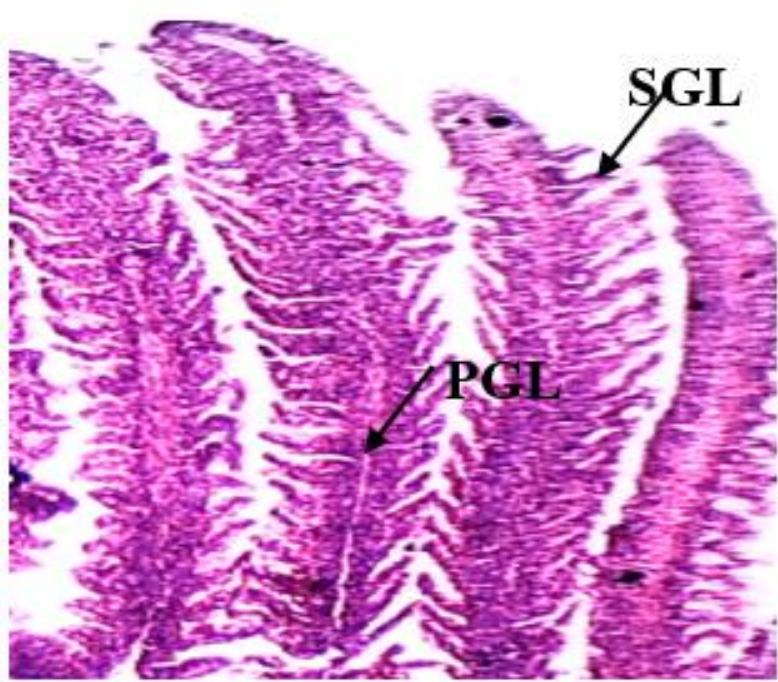

A

Figure - 1A. Section passing through gill of fish Gonoproktopterus kolus from control (10 X) PGL - Primary gill lamellae, SGL - Secondary gill lamellae.

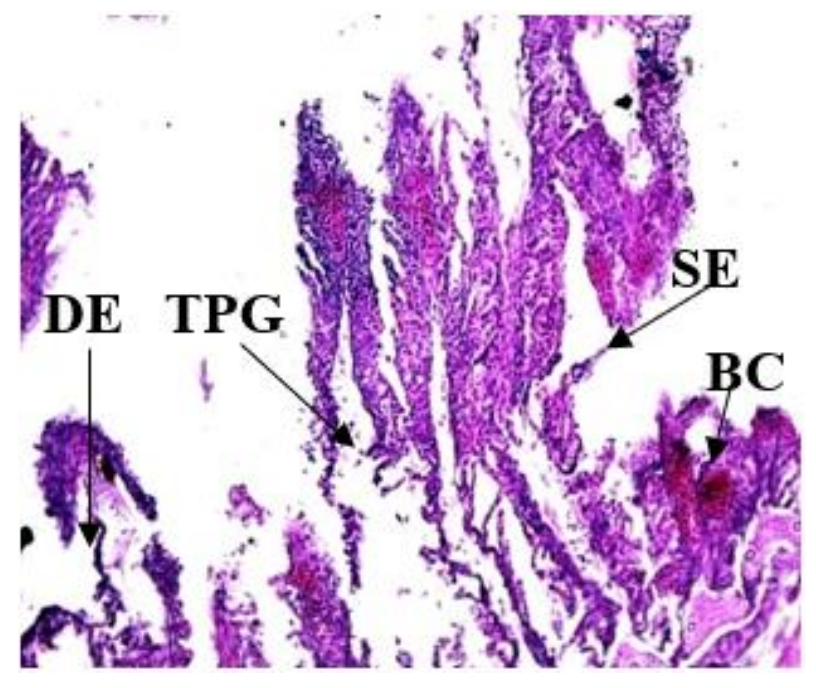

B

Figure - 1B. Effect of $2.430 \mathrm{ppm}$ of Zinc sulphate on gill of fish Gonoproktopterus kolus after 96 hrs. exposure (10 X). DE - Detached epithelium, BC - Clot, SE - Split skeletal epithelium, TPG - Thickened primary gill lamellae.

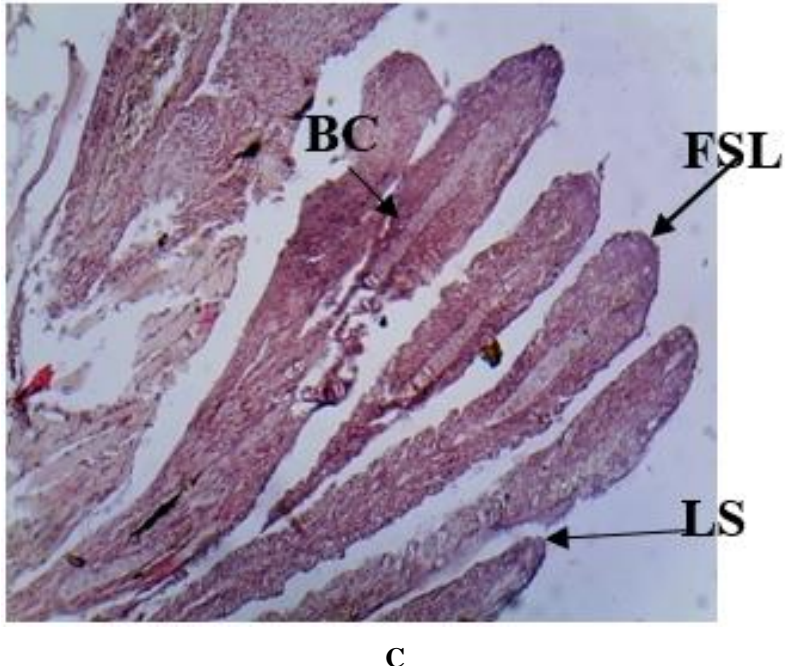

Figure - 1C. Effect of $4.860 \mathrm{ppm}$ of Zinc sulphate on gill of fish Gonoproktopterus kolus after 96 hrs. Exposure (10 X). FSL - Fused secondary lamellae, BC - Blood clot, LS - Loss of secondary lamellae.

\section{Histopathology of Liver:-}

The normal histological structure and changes induced by the effects of heavy metal at acute concentration are shown in Figure - 2 (Figure A to $\mathrm{C}$ ).

\section{Control of Acute Test -}

The histological structure of liver of fish from control set appeared to be normal. The mass of the liver is comprised of continuous polyhedral hepatocytes. The hepatocytes were organized in continuous cords of cells. Each hepatocyte contained granulated cytoplasm with central nucleus. At few places, blood sinusoids were seen in hepatic mass (Fig - 2A).

\section{Zinc Sulphate: Concentration 2.430 ppm:-}

Degeneration of cell wall leading to cirrhotic changes were observed. Extrusion of nuclei resulted due to precipitation and loss of cytoplasm. Degeneration of nuclei was also observed. Empty hepatic cells showed the shifting of the nucleus. Hepatocytes showed pyknosis that has given rise to vacuolation in the tissue (Fig -2B). 


\section{Zinc Sulphate: Concentration 4.860 ppm:-}

Hepatic cells showed hypertrophy due to degenerative changes in cellular structure. There was disarray of hepatic cords and large spaces were seen among the hepatic cells. Blood vessels showed dilation with empty blood sinusoids. Hepatic cells showed acute necrosis resulted into cirrhotic changes. Mixing of cytoplasm was seen due to degeneration of cell wall (Fig - 2C).

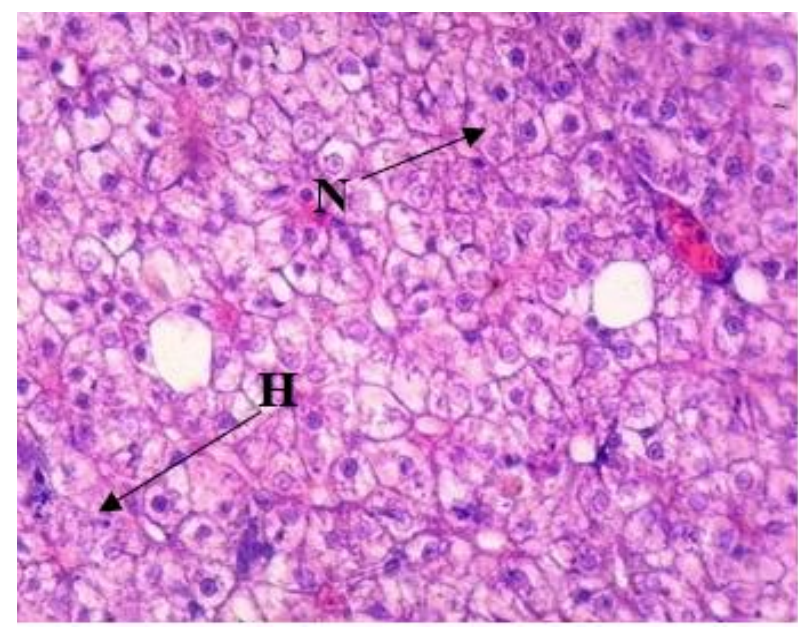

A

Figure - 2A. Section passing through liver of fish Gonoproktopterus kolus from control (400X). N - Nucleus, H - Hepatocytes

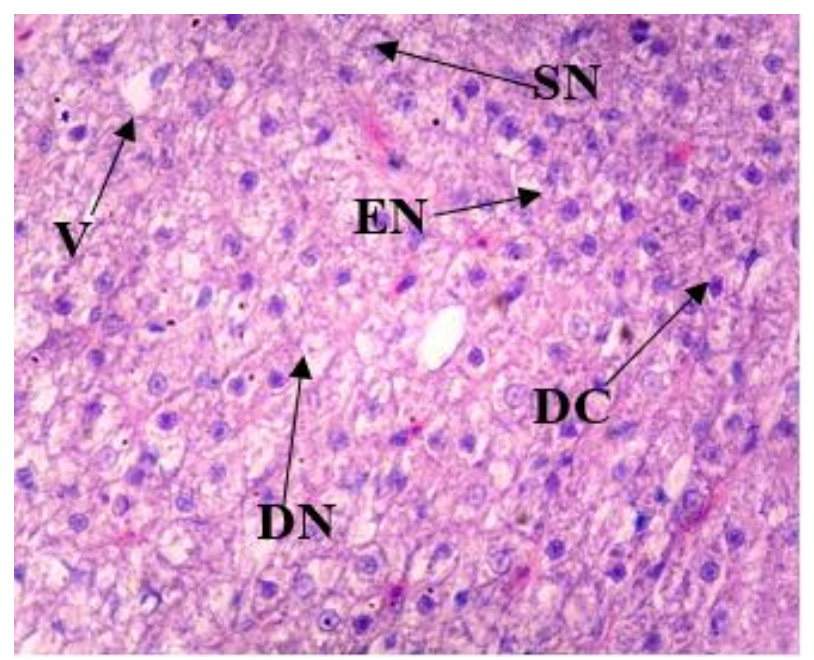

B

Figure - 2B. Effect of $2.430 \mathrm{ppm}$ of Zinc sulphate on liver of fish Gonoproktopterus kolus after $96 \mathrm{hrs}$. exposure $(400 \mathrm{X})$. DC Degenerating cell wall, DN - Degenerating nucleus, EN - Extruded nucleus, $\mathbf{S N}$ - Shifted nucleus, $\mathbf{V}$ - Vacuole.

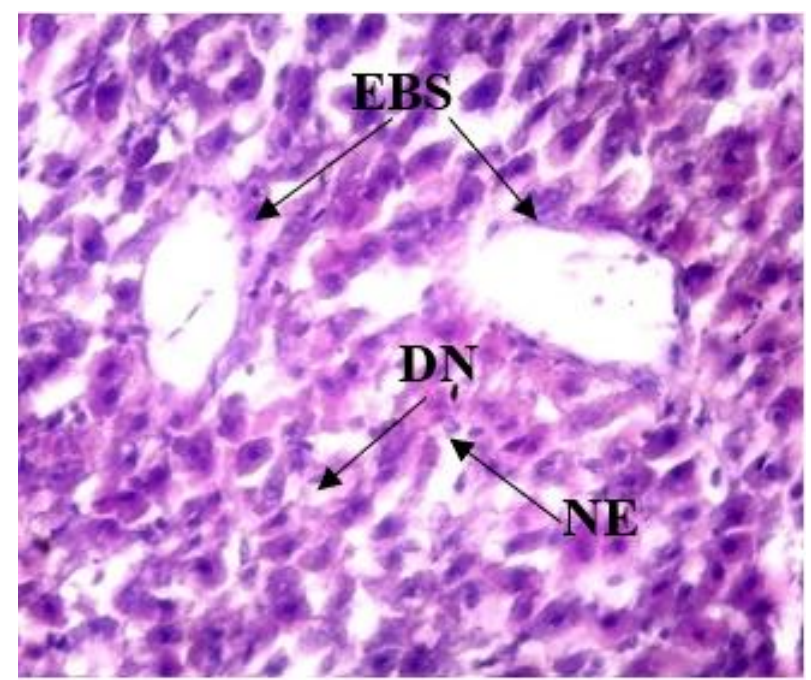

C

Figure - 2C. Effect of $4.860 \mathrm{ppm}$ of Zinc sulphate on liver of fish Gonoproktopterus kolus after 96 hrs. exposure (400 X). EBS - Empty blood sinus, DN - Degenerating nucleus, NE - Necrosis.

\section{Histopathology of Kidney:-}

The normal histological structures and changes induced by the effect of heavy metals at acute concentrations are shown in Figure - 3 (Figures A to C).

\section{Control of Acute Test -}

The kidney of the fish from control showed normal histological structure. The functional kidney consists of many renal tubules and hemopoetic tissue. The tubules were lined with epithelial cells, which were nucleated containing dense cytoplasm. The glomeruli of various sizes and shapes were found to be placed in Bowman's capsule. The proximal, distal, and collecting tubules were prominently observed (Fig - 3A).

\section{Zinc Sulphate: Concentration 2.430 ppm:-}

Degenerative nuclei were seen in the epithelial lining of the tubule. Empty space was observed around the tubule. The lumen of the tubule was occupied by slough from the cells. Disorganization of cells in the epithelium of the tubule was evident. Haemopoetic tissue showed hypertrophy and disarray. Distended glomerulus was observed (Fig - 3B). 


\section{Zinc Sulphate: Concentration 4.860 ppm:-}

Degeneration of nuclei and disorganization of epithelial cell of the tubule was prominent. Renal tubules showed disarrangement. Haemopoetic tissue exhibited hypertrophy and disarray. Many empty spaces were seen among the tissue. Lumen of the tubule was filled with the slough from the cells. At some places blood clots were also seen (Fig 3C).

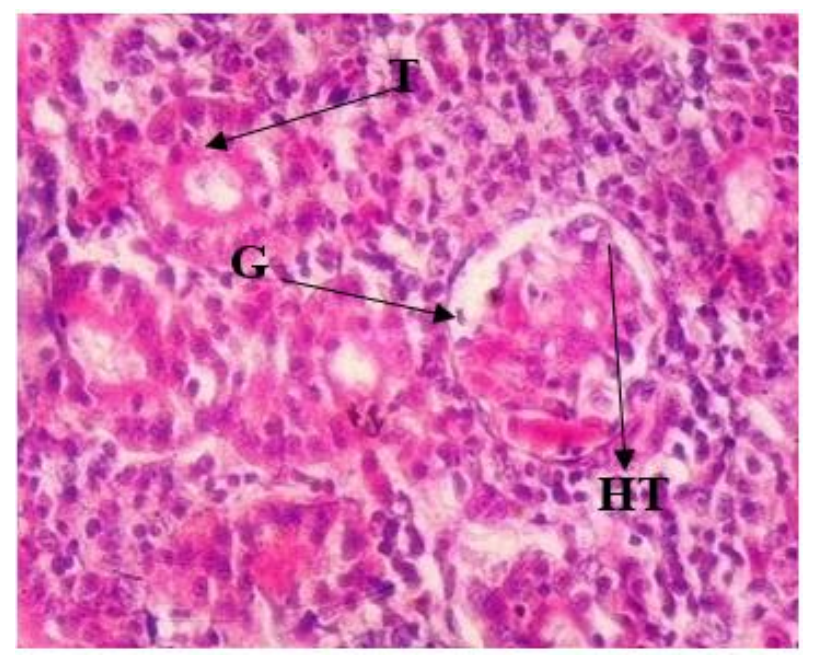

$\mathbf{A}$

Figure - 3A. Section passing through kidney of fish Gonoproktopterus kolus from control (400 X). T - Tubule, HT - Haemopoetic tissue, G Glomerulus.

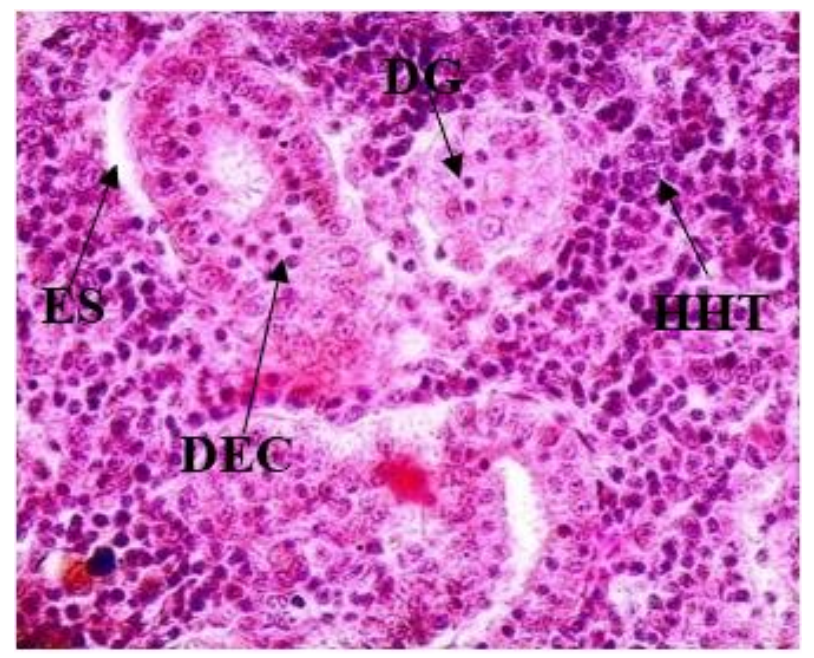

B

Figure - 3B. Effect of $2.430 \mathrm{ppm}$ of Zinc sulphate on kidney of fish Gonoproktopterus kolus after 96 hrs. exposure (400 X). DG - Distended glomerulus, HHT - Hypertrophy of haemopoetic tissue, ES - Empty space, DEC - Disorganized epithelial cells.

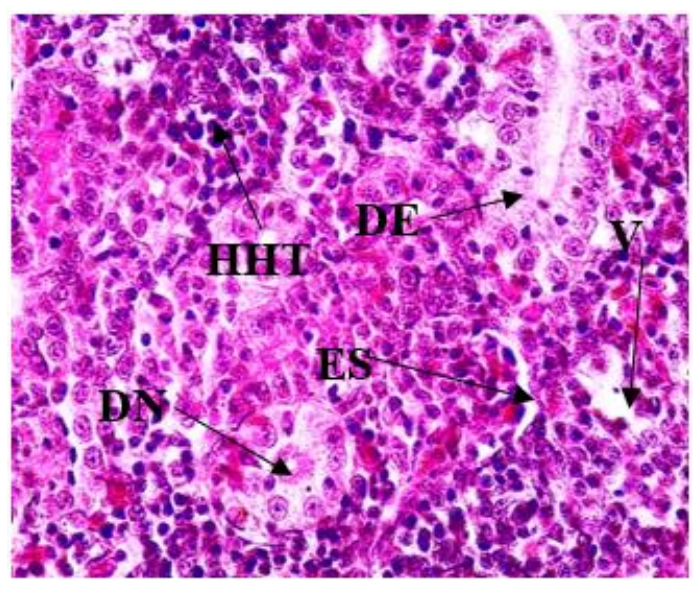

C

Figure - 3C. Effect of 4.860 ppm of Zinc sulphate on kidney of fish Gonoproktopterus kolus after 96 hrs. exposure $(400$ X).DE Degenerating epithelium, DN -Degenerating nucleus, HHT Hypertrophy of haemopoetic tissue, ES - Empty space, V - Vacuole.

Entry of heavy metals in the body leads to physiological, biochemical and pathological changes in fish. Histopathological changes in cellular structure of tissue and organs are irreversible resulting in malfunctioning of the organ, which finally results in death of a fish. The gills are main respiratory and osmoregulatory organ, which come in contact with surrounding water. Therefore, gills are the best indicators of any kind of aquatic pollution Pandey [26]. The impact of copper on gill and functional enzymes activity of carp Karan [19], Laurent [20], Au [2] and Camargo [4] showed that histopathological changes in fish gill were among very commonly recognized responses to environmental pollutions.

In present study after acute toxicity of zinc sulphate at $\mathrm{LC}_{50}$ concentration $(2.430 \mathrm{ppm})$, the tips and bases of primary gill lamellae showed hyperplasia and hypertrophy. There were degenerative changes in secondary gill lamellae and reduction in their length. At some places, destruction of second lamellae was observed. The fusion of secondary lamellae was also observed (Fig. - 1B). Similar results were observed when freshwater fish Tilapia mossambica was treated with cadmium sulphate Jalaludeen [14]. The gill of lead acetate exposed fish showed remarkable histopathological changes like hyperplasia of the epithelial cells that caused the merging of adjacent secondary gill lamellae. Besides this, the secondary lamellae became smaller and lamellar fusion formed swellings. Further, edema between the primary epithelium and secondary lamella, severe degeneration with fibrosis in primary filaments, and disappearance of inter lamellar spaces were also observed Pandi [27]. 
The liver of fish is a large vital organ. It has much functions comprising detoxifications, protein synthesis, storage of glycogen and production of biochemicals (bile) essential for digestion. Toxicants (Heavy metals) entering the body through the body surface, gills and gastrointestinal tract reach the liver through the blood. The liver is considered as an environmental biomarker, because of its capacity for detoxification and storage of harmful components Stori [31]. The present study after acute exposure, at $\mathrm{LC}_{0}$ concentration of zinc sulphate the liver showed degeneration of cell wall leading to cirrhotic changes. Extrusion of nuclei resulted due to precipitation and loss of cytoplasm. Degeneration of nuclei was also observed. Empty hepatocytes showed shifting of nucleus. Hepatocytes showed pyknosis that caused vacuolation in the tissue (Fig. 2B). At $\mathrm{LC}_{50}$ concentration of zinc sulphate, the hepatocytes showed hypertrophy due to degenerative changes in cellular structure. There was disarray of hepatic cords and large cavities were seen between the hepatic cells. Blood vessels showed dilation with empty blood sinusoids. Hepatocytes exhibited acute necrosis resulted into cirrhotic changes. Mixing of cytoplasm was seen due to degeneration of cell wall (Fig. 2C). These changes are usually linked with the reaction of hepatocytes to toxicants, Van [33]; Hinton [11]. These pathological changes also may be correlated to the vacuolation of hepatocytes that is interrelated with suppressed protein synthesis, energy depletion, breaking of microtubules, or alterations in substrate utilization, as described by, Ajani [1]. Cadmium treated Oreochromis niloticus showed, hepatocyte degeneration, with nuclear pyknosis in majority of the cells and the addition of metal binding proteins in their nuclei was reported by Kaoud [18]. Gaps in cytoplasm, deterioration of nuclei, vacuolation in stroma, hazy swellings, pycnotic nuclei, necrosis, break in blood sinusoids, disorder of hepatic cords, loss of shape of hepatocytes was witnessed in the liver of Channa gachua (Ham) exposed to mercury and copper Deore [7]. Increase of hemorrhage, vacuolation in hepatocytes and penetration of sinusoids with WBC's were noticed in liver of Nile Tilapia, Oreochromis niloticus after acute exposure to cadmium El-Sayed [8]. Cirrhinus mrigala exposed to mercury showed loss of cellular design, necrosis in hepatocytes and accumulation of fat in parenchymal cells of liver, Chavan [5]. Extensive hepatocyte necrosis with long-lasting inflammatory changes was detected in the liver of fishes exposed to $\mathrm{Cu}$ solution. Justina [16].

The kidneys are the organs of excretion. They also play a role in osmoregulation and detoxification. The kidney of freshwater fish functions for checking additional solute loss as they contain more salts within their blood than the surrounding water body. The kidney is an important vital organ of the body and proper function is to regulate the homeostasis. The kidney is not only liable for selective reabsorption, which assists in holding volume and $\mathrm{pH}$ of blood and body fluids and erythropoiesis Iqbal [13]. The kidney is one of the first organs to be influenced by contaminants in the water, Thophon [32]. During acute exposure ( $\mathrm{LC}_{0}$ concentration) to zinc sulphate, the epithelial lining of the tubule showed degenerative nuclei. Space was observed around the tubule. The slough from the cells was filled in the lumen of tubule. The epithelium of the tubule showed disorganization of cells. Hypertrophy and disarray was evident in the haemopoetic tissue. Distended glomerulus was observed (Fig. 3B). In $\mathrm{LC}_{50}$, concentration the epithelial cell of the tubule showed disorganization and degeneration of nuclei. Renal tubules showed disarrangement. Hypertrophy and disarray was observed in haemopoetic tissue. Many empty spaces were observed among the tissue. Lumen of the tubule was filled with the slough from the cells. At some places blood clots were also seen (Fig. 3C). Similar findings such as enlargement of renal tubules, desquamation of epithelial lining, edema, severe necrosis, pyknotic nuclei, hypertrophied nuclei, vacuolization, disorganized blood capillaries in glomerulus were observed in the kidney of Channa punctatus treated with a sub-lethal concentration of zinc, Gupta [10]. Intracellular spaces between the cells, irregularly shaped cells and necrosis were observed in the kidney of Hoplias malbaricus exposed to methyl mercury, Mela [17]. The authors suggested that the cause histopathological abnormalities are due to high accumulation of zinc in the kidney probably dysfunction the detoxification mechanism of renal tissue in it. Aggregation of inflammatory cells, capillary tubes dilation of renal tubule, and hemolysis in the kidney of Cyprinus carpio, was observed after exposure to chromium at sub-lethal concentration, Rana [29].

\section{Conclusions}

Histopathology is a useful method for exploring the effect toxicants in various organs of the treated organisms. In present study, gill, liver, and the kidney of the fishes exposed to acute concentrations of zinc sulphate showed several drastic degenerative histological changes. The result showed that these degenerative changes might lead to malfunctioning of the organ. Any single factor cannot be related to changes in cellular architecture and may be dependent on the cumulative effects of many factors induced by the presence of heavy metals in the body of fishes.

\section{Acknowledgements}

The authors are thankful to the Principal and HOD of Dept. of Zoology Y. C. Institute of Science, Satara, for providing necessary facilities to carry out present work. The authors are also grateful to UGC (Western Region office), Pune Maharashtra, INDIA, for sanction of study leave under FIP. 


\section{REFERENCES}

[1] Ajani, E. K. and Akpoilih, B. U. J. (2010): Effect of chronic dietary copper exposure on hematology and histology of common carp (Cyprinus carpio L.). J. appl. Sci. Environ. Manage. 14: 39-45.

[2] Au. D.W.T. (2004): The application of histocytopathological biomarkers in marine pollution monitoring: a review, Marine Pollution Bulletin, 48: 817-834

[3] Berman SC, Lal MN (1994): Accumulation of heavy metals $(\mathrm{Zn}, \mathrm{Cu}, \mathrm{Cd}$ and $\mathrm{Pb})$ in soil and industrially polluted fields. Journal of Environmental Biology. 15:107-115.

[4] Camargo, M.M. and Martinez, C. B. (2007): Histopathology of gills, kidney and liver of a Neotropical fish caged in an urban stream. Neotrop. Ichthyol., 5: 327-336.

[5] Chavan V.R. and D. V. Muley (2014): Effect of heavy metals on liver and gill of fish Cirrhinus mrigala. Int. J. Curr. Microbiol. App. Sci. Vol. 3(5): 277-288.

[6] Chopra R, Verma VK, Sharma PK. (2001): Mapping monitoring and conservation of Harike wetland ecosystem, Punjab, India, through remote sensing. International Journal of Remote Sensing. 22:89-98. 10.

[7] Deore S. V. and S.B. Wagh (2012): Heavy metal induced histopathological alterations in liver of Channa gachua (Ham). Journal of Experimental Sciences, 3(3): 35-38.

[8] El-Sayed Mohamed Younis, Abdel-Wahab Abdel-Moez Abdel-Warith, Nasser Abdualla Al-Asgah, Hossam Ebaid and Mohamed Mubarak (2013): Histological Changes in the Liver and Intestine of Nile Tilapia, Oreochromis niloticus, Exposed to Sublethal Concentrations of Cadmium. Pakistan J. Zool., vol. 45(3), pp. 833-841.

[9] Figuiredo- Fernandes A., Rontainhas Fernandes A., Rocha E. and Reis- Henriques M. A. (2006): The effect of paraquat on hepatic EROD activity, liver and gonadal histology in males and females of Nile Tilapia, Oreochromis niloticus, exposed at different temperatures. Archives of Environmental Contamination and Toxicology, 51(4): 626-632.

[10] Gupta P., and Srivastava N. (2006): Effects of sub-lethal concentrations of zinc on histological changes and bioaccumulation of zinc by kidney of fish Channa punctatus (Bloch). Journal of Environmental Biology. 27(2):211-215.

[11] Hinton, D. E. and Laure'n, D. J. (1990): Integrative histopathological effects of environmental stressors on fishes. Am. Fish. Soc. Symp., 8: 51-66.

[12] Ho E. (2004): Zinc deficiency, DNA damage and cancer risk. J. Nutr. Biochem., 15: 572-578.

[13] Iqbal, F., Qureshi, I. Z. and Ali, M. (2004): Histopathological changes in the kidney of common carp, Cyprinus carpio following nitrate exposure. J. Res. Sci., 15: 411-418.

[14] Jalaludeen, M.D., Arunachalam, M., Raja, M., Nandagopal, S., Showket Ahmad Bhat, Sundar, S. Palanimuthu, D. (2012): Histopathology of gills, liver and kidney tissues of freshwater fish Tilapia mossambica expose to cadmium sulphate. International journal of Advanced Biological Research. VOL. 2(4) 572-578.

[15] Joshi, H.C., (1990): Environmental constrains in management of fisheries in open water system. Proceedings of the National Seminar on Management of fisheries in Inland open water system of India, Barracpore, West Bengal India. Dec. 1988. (1990), 23-30.

[16] Justina I. R. Udotong (2015): Histopathological Changes in Liver and Muscle of Tilapia Fish from QIRE Exposed to Concentrations of Heavy Metals. International Journal of Biotechnology and Bioengineering Vol:9, No:6, 659 - 662.

[17] Mela, M., Randi, M. A. F., Ventura, D. F., Carvalho, E., Pelletier, C. E. V. and Oliveira, C. A. (2007): Effect of dietary methyl mercury on liver and kidney of histology of neptropical fish Hoplias malabaricus. Eco. Environ. Safe 68(3),426-426.

[18] Kaoud, H. A., Zaki, M. M., El-Dahshan, A. R., Saeid, S. and El Zorba, H. Y., (2011): Amelioration the toxic effects of cadmium-exposure in Nile Tilapia (Oreochromis niloticus) by using Lemnagibba L. Life Sci. J., 8: 185-195.

[19] Karan V., Vitorovic S., Tutundzic V. \& Poleksic V. (1998): Functional enzymes activity and gill histology of carp after copper sulfate exposure and recovery. Ecotoxicol. Environ. Safety 40:49-55.

[20] Laurent, P. and Perry, S.F. (1991). Environmental effects on fish gill morphology. Physiol. Zool., 53:4-25

[21] Mabrouk D.R. (2004): Aspects of Manzalah Lake pollution on Mugil species. M. Sc. Thesis, Faculty of Girls, Ain Shams University, Egypt. 293.

[22] Maity S, Roy S, Chaudhury S, Bhattacharya S (2008). Antioxidant responses of the earthworm Lampito mauritii exposed to $\mathrm{Pb}$ and $\mathrm{Zn}$ contaminated soil. Environ. Pollut., 151: $1-7$.

[23] Nriagu, J.O. and J.M Pacyna., (1988): Quantitative assessment of worldwide contamination of air, water and soils by trace metals. Nature 333: 134-139.

[24] Oliveira Ribeiro C. A., Vollaire Y., Sanchez-Chardi A., Roche H. (2005): Bioaccumulation and the, effects of organochlorine pesticides, PAH and heavy metals in the eel (Anguilla anguilla) at the Camargue Nature Reserve, France. Aquatic Toxicology. 74:53-69.

[25] Palaniappan P. R., Vadivelu M., Vijaysundrum V. (2009): Fourier transform raman Spectroscopic analysis of lead exposed muscle tissue of Catla catla. Romanian Journal of Biophysics. 19:117-125.

[26] Pandey, A.K., S.Z. Siddiqui and K.V. Rama Rao (1993): Physico-chemical and biological characteristics of Hussainsagar, an industrially polluted lake, Hyderabad. Proc. Acad. Environ. Biol. 2(2); 161-167.

[27] Pandi Prabha, S. and Johanna Rajkumar, (2015): Histological study on protective effect of aquatic weed Hydrilla verticillata against lead induced toxicity in fish. International Journal of Pharmacy and Pharmaceutical Sciences. Vol 7, Issue 8, 132-136.

[28] Rabitto I.S., Alves Costa JRM, Silva de Assis HC, Pelletier E., Akaishi F.M., Anjos A. (2005): Effects of dietary Pb (II) and tributylin on neotropical fish, Hoplias malabaricus: 
histopathological and biochemical findings. Ecotoxicology and Environmental Safety. 60:147156.

[29] Rana M. A, Jabeen F, Shabbir S, Naureen A, Sultana K, Ahmad I (2015): Histopathological study of liver and kidney in common carp (Cyprinus carpio) exposed to different doses of potassium dichromate. International Journal of Biosciences. 6(12):108-116.

[30] Soufy H. M., Soliman E., Manakhly EI. and Gaafa A. (2009): Some biochemical and pathological investigations on monosex Tilapia following. Bull. Environ. Contamin. Toxicol. 43: 315320.

[31] Stori, E.M., Rocha, M.L.C.F., Dias, J.F., Dos Santos, C.E.I., de Souza, C.T., L. Amaral and J. F. Dias (2014) :Nuclear Instruments and Methods in Physics Research Section B: Beam Interactions with Materials and Atoms. Elsevier, Volume 318, Part A, 1 January, Pages 83-87.

[32] Thophon S., Kruatrachue M., Upatham E., Pokethitiyook P., Sahaphong S., Jaritkhuan S. (2003): Histopathological alterations of white sea bass, Lates calcarifer, in acute and subchronic cadmium exposure. Environmental Pollution. 121:307-320.

[33] Van Dyk J.C., Pieterse G.M., and VanVuren JHJ (2007): Histological changes in the liver of Oreochromis mossambicus (Cichlidae) after exposure to cadmium and zinc. Ecotoxicol. Environ. Safety, 66(3): 432-440. 